\title{
Uwagi w sprawie interpretacji zasad wyznaczania zasięgu rozrzutu odłamków skalnych $w$ robotach strzałowych
}

\author{
Krzysztof BARAŃSKI ${ }^{1)}$, Ryszard MORAWA ${ }^{2}$
}

\footnotetext{
1) dr inż.; AGH University of Science and Technology, Faculty of Mining and Geoengineering, Department of Surface Mining (Cracow, Poland); email: baranski@agh.edu.pl

2) dr inż.; AGH University of Science and Technology, Faculty of Mining and Geoengineering, Department of Surface Mining (Cracow, Poland); email: morawa@agh.edu.pl
}

\section{http://doi.org/10.29227/IM-2020-01-26}

Submission date: 20-12-2019 | Review date: 28-01-2020

Abstrakt
W referacie omówiono rodzaje metod wykonywania prac strzałowych w odniesieniu do rozrzutu odłamków skalnych. Omówiono
zasady wyznaczania stref zagrożen wokót miejsca strzelania na podstawie obecnie obowiazujacych przepisów prawnych. Przeanali-
zowano wpływ wskaźników technologicznych strzelania w zależności od metody prowadzenia prac strzałowych, majacych wplyw na
zasięg rozrzutu. Przedstawiono uwagi dotyczace szacowania zasiegu strefy rozrzutu w zależności od wskaźników technologicznych
strzelania (np. jednostkowe zużycie) uwzględniając regulacje prawne szacowania zasiegu rozrzutu przy różnych metodach prowadze-
nia prac strzałowych.

Słowa kluczowe: metody strzelania, wskaźnik działania ładunku, jednostkowe zużycie, strefa rozrzutu

\section{Wprowadzenie}

Stosowanie materiałów wybuchowych do wykonywania prac strzałowych w górnictwie jest przyczyną powstawania szeregu niekorzystnych oddziaływań na środowisko takich jak: drgania parasejsmiczne, propagacja powietrznej fali uderzeniowej (PFU), rozrzut, zapylenie, hałas itd. Jednym z najtrudniejszych do oszacowania i niepożądanych zjawisk jest rozrzut mas skalnych powstały w wyniku oddziaływania detonacji. Problematyczne jest oszacowanie zasięgu strefy możliwego rozrzutu.

W literaturze dostępne są wzory matematyczne pozwalające wyliczyć prognozowany zasięg promienia strefy rozrzutu. W polskim prawodawstwie istnieją przepisy prawne, które określają graniczne odległości od miejsc wykonywania robót strzałowych, zagrożone rozrzutem po przekroczeniu których, nie powinno obserwować się tego zjawiska. Są to wartości podane w postaci stabelaryzowanej określające graniczne możliwe wartości rozrzutu w zależności od metody wykonywania robót strzałowych oraz kierunku zagrożenia.

Pomimo stosowania się do wytycznych określonych w przepisach zdarzają się przypadki, w wyniku których odłamki skalne przekraczają ustalone strefy bezpieczeństwa co stanowi zagrożenie dla mienia i życia ludzi. Niekiedy też przyjmowanie promienia strefy rozrzutu „na sztywno” prowadzi do utraty dużych partii złoża gdy eksploatacja zbliża się do granic terenu górniczego. Dowodzi to, że istnieje potrzeba doprecyzowania lub wprowadzenia zmian w przepisach określających sposób wyznaczania zasięgu rozrzutu dla konkretnych prac strzałowych.

\section{Sposoby wyznaczania zasięgu rozrzutu}

Do wyznaczania strefy rozrzutu odłamków skalnych należy stosować przepisy górnicze określone $\mathrm{w}$ regulacjach prawnych dotyczących używania materiałów wybuchowych w zakładach górniczych. W przypadku konieczności zmiany tych wartości (zmniejszenia) podyktowanych potrzebami danej kopalni, wyznaczone strefy mogą zostać zmniejszone na podstawie opinii rzeczoznawcy poprzedzonej szczegółową analizą sytuacji oraz podpartą obliczeniami inżynierskimi.

\subsection{Uwarunkowania prawne stosowane przy wyznaczaniu zasięgu strefy rozrzutu}

Sposób wyznaczania zasięgu strefy rozrzutu określają przepisy górnicze zawarte Rozporządzeniu Ministra Energii z dnia 9 listopada 2016 r. w sprawie szczegółowych wymagań dotyczących przechowywania i używania środków strzałowych i sprzętu strzałowego w ruchu zakładu górniczego (Dz. U. $2017 \mathrm{nr}$ 321). Dokładne wytyczne dotyczące rozrzutu zawarte są w załączniku 4 rozporządzenia: „Wyznaczanie strefy zagrożenia wokół miejsca wykonywania robót strzałowych w odkrywkowych zakładach górniczych, zakładach górniczych wydobywających kopaliny otworami wiertniczymi”.

Wielkości promienia strefy zagrożenia ze względu na rozrzut odłamków skalnych określa się w zależności od stosowanej metody wykonywania robót strzałowych, typu wyrobiska górniczego, sytuacji terenowej i rodzaju urabianej skały. Wartości te zestawiono w tab. 1 załącznika 4 rozporządzenia (tab. 1).

Podstawową technologią robót strzałowych jest strzelanie ładunkami umieszczonymi w otworach strzałowych. Metody wykonywania robót strzałowych podzielono w Rozporządzeniu na (Dz. U. $2017 \mathrm{nr}$ 321):

- $\quad$ strzelanie ładunkami otworach krótkich, z poszerzonym dnem o różnym stopniu nachylenia,

- strzelanie ładunkami w otworach krótkich, z poszerzonym dnem oraz $\mathrm{w}$ progach przyspągowych, 
Tab. 1. Wielkości strefy zagrożenia ze względu na rozrzut odłamków skalnych (Dz. U. $2017 \mathrm{nr}$ 321)

Tab. 1. The size of the danger zone due to the scattering of rock fragments (Journal of Laws of 2017 No. 321)

\begin{tabular}{|c|c|c|c|}
\hline \multirow{2}{*}{ Metoda wykonywania robót strzałowych } & \multicolumn{3}{|c|}{$\begin{array}{l}\text { Wielkość strefy zagrożenia ze względu na rozrzut } \\
\text { odlamków skalnych w metrach }\end{array}$} \\
\hline & $\begin{array}{c}\text { Wokół miejsca } \\
\text { strzelania }\end{array}$ & $\begin{array}{c}\text { Do wyrobiska } \\
\text { górniczego }\end{array}$ & $\begin{array}{l}\text { Poza wyrobisko } \\
\text { górnicze }\end{array}$ \\
\hline $\begin{array}{l}\text { Strzelanie ładunkami w otworach krótkich i z } \\
\text { poszerzonym dnem: } \\
\text { pionowych } \\
\text { poziomych i nachylonych }\end{array}$ & 300 & 400 & 200 \\
\hline $\begin{array}{l}\text { Strzelanie ładunkami w otworach krótkich i z } \\
\text { poszerzonym dnem w } \\
\text { progach przyspągowych }\end{array}$ & 400 & ------- & -------- \\
\hline $\begin{array}{l}\text { Strzelanie w celu poszerzania dna otworów } \\
\text { krótkich i długich }\end{array}$ & 100 & -------- & -------- \\
\hline $\begin{array}{l}\text { Strzelanie ładunkami } w \text { długich otworach: } \\
\text { pionowymi } \\
\text { poziomymi i nachylonymi }\end{array}$ & 200 & 400 & 200 \\
\hline $\begin{array}{l}\text { Roboty strzałowe rozszczepkowe: } \\
\text { ładunkami nakładanymi } \\
\text { ładunkami podkładanymi } \\
\text { ładunkami w otworach z przybitką } \\
\text { lontem detonującym z przybitką wodną } \\
\text { ładunkami w otworach bez }\end{array}$ & $\begin{array}{l}300 \\
400 \\
300 \\
200 \\
200\end{array}$ & $\begin{array}{l}------ \\
----- \\
------ \\
------ \\
------\end{array}$ & $\begin{array}{c}------ \\
------ \\
------ \\
------ \\
------\end{array}$ \\
\hline Strzelanie komorowe i chodnikowe & 500 & ------- & ------- \\
\hline $\begin{array}{l}\text { Strzelanie na wyrzut i zrzut, kawernami, } \\
\text { szczelinowe, zestrzeliwanie nawisów } \\
\text { skalnych }\end{array}$ & 500 & -------- & ------- \\
\hline
\end{tabular}

- $\quad$ strzelania w celu poszerzenia dna otworów krótkich i długich,

- $\quad$ strzelania ładunkami w długich otworach, różnie nachylonych,

- roboty strzałowe rozszczepkowe,

- strzelania komorowe i chodnikowe,

- strzelanie rozszczepkowe $\mathrm{z}$ różnym rodzajem umieszczenia ładunków,

- $\quad$ strzelania określano jakie inżynierskie np. strzelanie na zrzut, wyrzut, szczelinowe, zestrzeliwanie nawisów itp.

W nowym rozporządzeniu zdefiniowano oraz wprowadzono podział otworów strzałowych ze względu na ich: długość, nachylenia i przekrój poprzeczny (Dz. U. 2017 nr 321).

Ze względu na długość otwory strzałowe dzielą się na:

- $\quad$ krótkie (długość mierzona od wylotu do dna otworu wynosi do $6 \mathrm{~m}$ ),

- $\quad$ długie (długość mierzona od wylotu do dna otworu wynosi więcej niż $6 \mathrm{~m}$ ).

Ze względu na nachylenie otwory strzałowe dzielą się na:

- pionowe (otwory pionowe i odchylone od pionu do 20),

- $\quad$ poziome (otwory poziome i odchylone od poziomu do 20),

- nachylone (otwory o kącie odchylenia od pionu większym niż 20 i mniejszym niż 70).

Przy wyznaczaniu zasięgu rozrzutu dopuszczalne są pewne odstępstwa (zmniejszenie stref) jedynie na podstawie opinii rzeczoznawcy. Z powyższych względów wynika, że w danej kopalni rozrzut może być zarówno większy jak i mniejszy od wielkości podanych w przepisach. Dlatego określenie właściwej wielkości promienia strefy rozrzutu ma istotne znaczenie dla kopalń. W sytuacji gdy w obrębie jednego zakładu górniczego prowadzi się prace strzałowe $\mathrm{z}$ wykorzystaniem różnych metod strzelania w różnych przodkach, dla każdej metody należy wyliczyć zasięg strefy rozrzutu oddzielnie.

\subsection{Empiryczne metody wyznaczania zasiegu rozrzutu}

Zasięg rozrzutu może być też prognozowany za pomocą wzorów empirycznych podanych w literaturze. Najczęściej stosowane wzory oparte są na zależności pomiędzy wskaźnikiem działania ładunku i zabiorem: (Barański, 2015; Barański, 2016; Barański, Morawa, 2015; Korzeniowski, Onderka, 2006)

$R_{r}=20^{*} n^{2 *} z$

gdzie:

$R_{r}$ - zasięg strefy rozrzutu $[\mathrm{m}]$,

$n$ - wskaźnik działania ładunku MW [-],

$z$ - zabiór [m].

Do strzelania metodą długich otworów strzałowych zaleca się wykorzystywanie także wzoru:

$R_{r}=2 / 3 * z\left(1+n^{2}\right)^{4}$

gdzie:

$R_{r}$ - zasięg strefy rozrzutu $[\mathrm{m}]$,

$n$ - wskaźnik działania ładunku MW [-],

$z$-zabiór [m].

Promień strefy rozrzutu można obliczyć także za pomocą wzoru Pokrowskiego uwzględniającego zabiór i masę objętościową skały oraz wielkość ładunku:

$R_{r}=\frac{2}{3} * z\left[1+\left(2200 * \frac{Q}{\gamma_{0} * z^{3}}-0,7\right)^{\frac{2}{3}}\right]^{4}$

Wzór ten dostarcza dobrych wyników dla strzelania w małych średnicach mniejszych od $40 \mathrm{~mm}$ i zabiorach do 1 m głównie dla ładunków skupionych. Przy strzelaniach w większych średnicach i zabiorach większych jak $2 \mathrm{~m}$ wpro- 

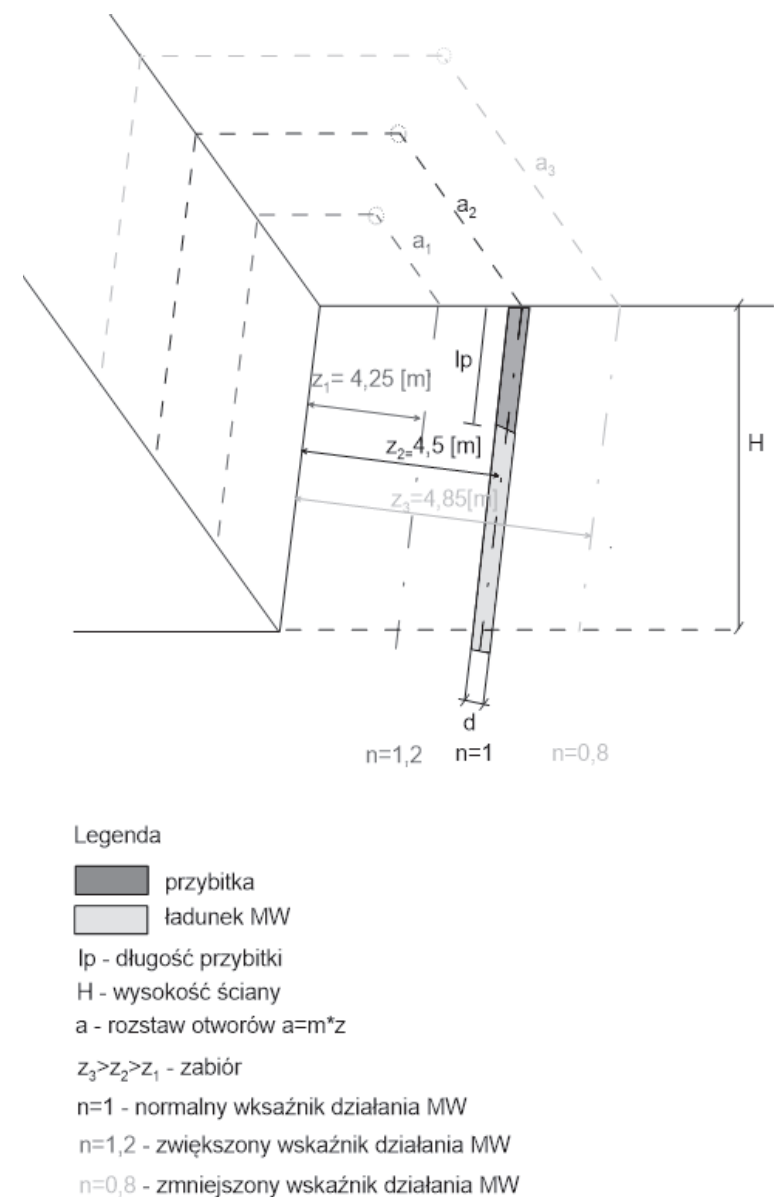

Rys. 1. Wpływ zabioru na zmianę wskaźnika działania „n” (Barański, 2016)

Fig. 1. Influence of the web on the change of the "n" operation indicator (Barański, 2016)

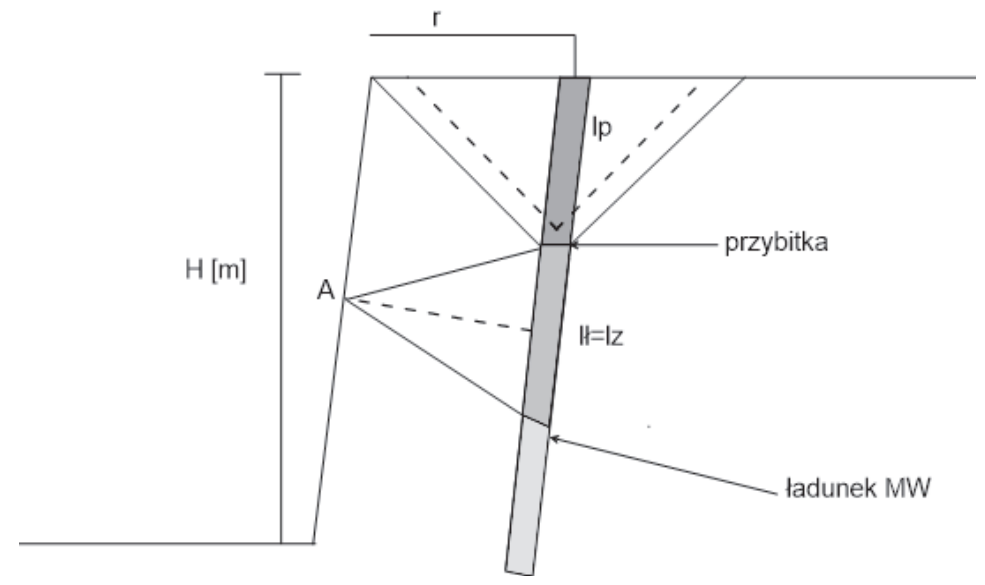

Rys. 2. Stożek wyrzutu odłamków skalnych (Barański, Morawa, 2015)

Fig. 2. Cone ejection rock fragments (Barański, Morawa, 2015)

wadza się następującą poprawkę:

$$
R_{r}=\frac{2}{3} * z\left[1+\left(2200 * \frac{Q}{\gamma_{0} * z^{3}}\right)^{\frac{2}{3}}\right]^{4}
$$

gdzie:

$R_{r}$ - zasięg strefy rozrzutu $[\mathrm{m}]$,

$z$ - zabiór $[\mathrm{m}]$,

$\gamma 0$ - masa objętościowa skały $\left[\mathrm{kg} / \mathrm{m}^{3}\right]$,

$Q$ - wielkość ładunku oddziaływująca na element skalny (najczęściej ładunek w otworze strzałowym) [kg].
Do obliczania promienia strefy rozrzutu można zastosować także inny wzór, którego formuła uwzględnia wielkość oddziałującego ładunku, prędkość początkową lotu odłamka, a także współczynniki geologiczno-górnicze:

$$
R_{r}=\left(\frac{\alpha * k_{w}}{v}\right)^{\frac{2}{3}} * Q^{\frac{1}{3}}
$$

Prędkość początkową wyrzucanego odłamka wylicza się ze wzoru:

$$
v=\sqrt{\frac{2}{3} * z * q\left(1+n^{2}\right)}
$$




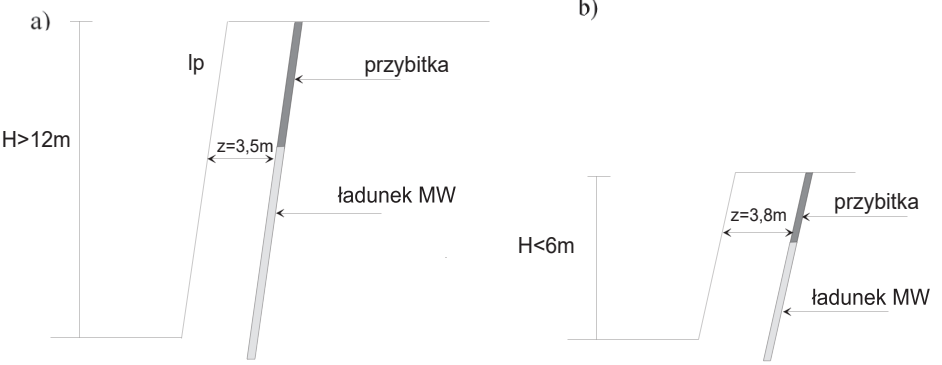

Rys. 3. Prowadzenie prac strzałowych $\mathrm{z}$ wykorzystaniem długich a) i krótkich b) otworów

Fig. 3. Carrying out blasting works using long a) and short b) blast holes

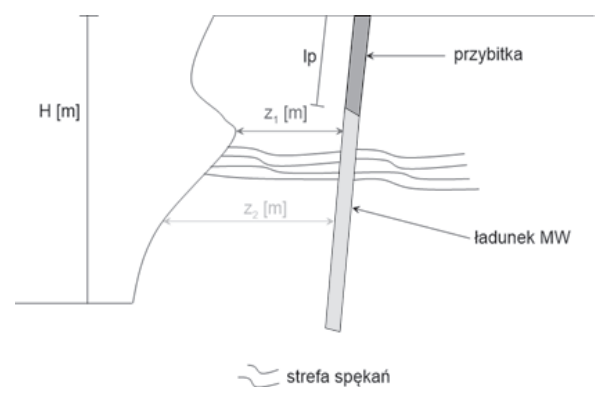

Rys. 4. Wpływ nierówności ściany na zmianę zabioru (Barański 2016)

Fig. 4. Impact of wall unevenness on the change of the web (Barański 2016)

gdzie:

$R_{r}$ - zasięg strefy rozrzutu $[\mathrm{m}]$,

$z$-zabiór $[\mathrm{m}]$,

$k_{w}$ i a - współczynniki zależne od warunków górniczo-geologicznych strzelania, w literaturze zaleca się odpowiednio przyjąć: $\alpha=177-210, k_{w}-1,5 \div 1,9$,

$v$ - prędkość początkowa lotu odłamka $[\mathrm{m} / \mathrm{s}]$,

$q$ - jednostkowe zużycie MW $\left[\mathrm{kg} / \mathrm{m}^{3}\right]$.

Z uwagi na dużą liczbę trudnych do oszacowania zmiennych, wzór ten może być obarczony sporymi błędami polegającymi na niedoszacowaniu przewidywanego zasięgu rozrzutu odłamków.

\section{Uwagi dotyczące sposobu wyznaczania zasięgu rozrzutu} na podstawie obecnie obowiązujących przepisów prawnych 3.1 Parametry strzelania wptywające na zasięgu strefy rozrzutu

Do podstawowych parametrów strzelania można zaliczyć:

- wskaźnik działania ładunku „n” definiowany jako stosunek promienia stożka działania ładunku do zabioru,

- jednostkowe zużycie MW „q” definiowane jest jako ilość materiału wybuchowego potrzebną do urobienia $1 \mathrm{~m}^{3}$ skały,

- $\quad$ zabiór „z” jest to najkrótsza odległość pomiędzy osią otworu strzałowego a powierzchnią odsłonięcia mierzona pod kątem $90^{\circ}$ do osi otworu.

Jednym $\mathrm{z}$ najistotniejszych parametrów prac strzałowych pozwalających przewidywać zasięg strefy rozrzutu jest wskaźnika działania ładunku „n” (Korzeniowski, Onderka, 2006). Wskaźnik działania ładunku „n” określa kształt stożka działania MW. Został on zdefiniowany w załączniku nr 4 do Rozpo- rządzenia w postaci wzoru (Dz. U. $2017 \mathrm{nr}$ 321):

$n=R / z$

gdzie:

$n$ - wskaźnik działania ładunku,

$R$ - promień podstawy stożka działnia, wyrażony w metrach, $z$ - zabiór otworów strzałowych.

W zależności od wartości wskaźnika przyjmuje się następujące wartości:

dla $\mathrm{n}=1$ wartość normalną wskaźnika,

dla $\mathrm{n}<1$ wartość zmniejszoną,

dla $\mathrm{n}>1$ wartość zwiększoną wskaźnika.

Większość robót strzałowych projektuje się przyjmując $n$ = 1 (ładunek normalny) i dla takiej wartości określa się zapotrzebowanie energii na urobienie. W zależności od celów technologicznych strzelania istnieje możliwość niwelowania zagrożenia rozrzutem za pomocą zmiany tego parametru. Zbyt wysokie zużycie jednostkowe MW powoduje przesycenie energetyczne urabianego ośrodka skalnego, co może manifestować się w postaci niekorzystnych oddziaływań na środowisko w postaci m.in. drgań parasejsmicznych, PFU oraz zwiększonego rozrzutu. Istnieje zależność pomiędzy zużyciem jednostkowym a zabiorem i wskaźnikiem działania MW. Zmiana każdego z tych parametrów powoduje zmianę wartości pozostałych (Barański, Morawa, 2015). Zakładając, że ilość MW w otworze jest wartością stałą można zauważyć, że:

- zwiększając zabiór zwiększa się objętość calizny, która ma zostać urobiona przez taką samą ilość MW, co powoduje obniżenie zużycia jednostkowego MW. Prowadzi to do strzelania z tzw. zmniejszonym wskaźnikiem działania „n”, który z uwagi na zasięg rozrzutu jest korzystny. Występuje mniejsza koncen- 


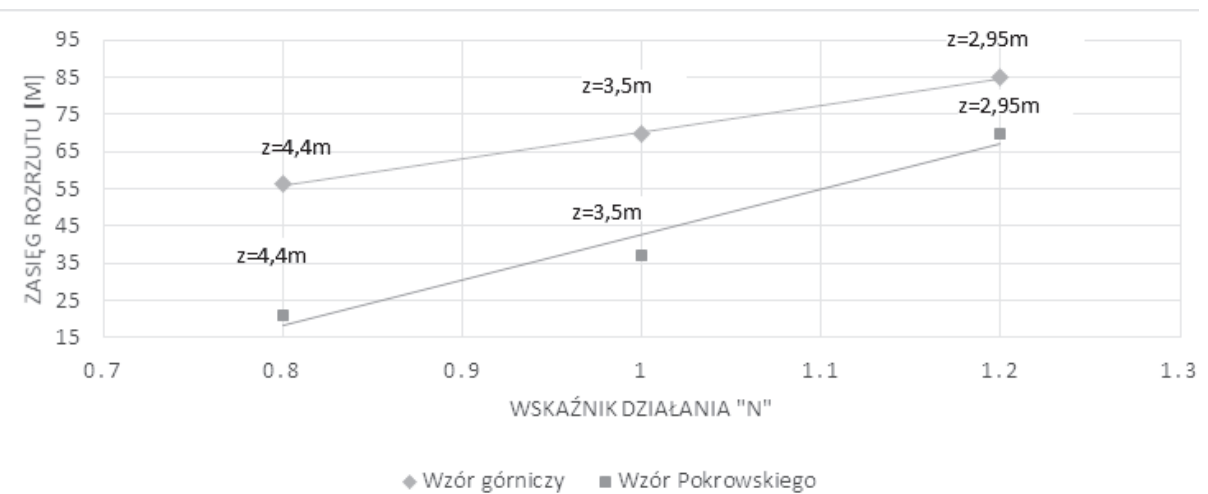

Rys. 5. Porównanie zasięgów rozrzutu przy zmieniającym się wskaźniku działania „n” oszacowanych za pomocą dwóch wzorów obliczeniowych (Barański 2016)

Fig. 5. Comparison of scattering ranges with the changing "n" action indicator estimated using two calculation formulas (Barański 2016)

tracja energii MW.

- zmniejszając zabiór zwiększa się objętość calizny, która ma zostać urobiona przez taką samą ilość MW, co powoduje zwiększenie zużycia jednostkowego MW. Prowadzi to do strzelania $\mathrm{z}$ tzw. zwiększonym wskaźnikiem działania „n”, który z uwagi na zasięg rozrzutu jest niekorzystny - występuje efekt „przesycenia energetycznego" ośrodka skalnego.

Powyższe zależności w sposób graficzny prezentuje rys. 1.: Autorzy proponują przyjąć pewną poprawkę we wzorach, których formuły zawierają wskaźnik „n”. W celu efektywnego stosowania wzorów empirycznych zasadne jest przyjęcie pewnych założeń (rys. 2.):

- ponieważ ładunek zdetonowany $\mathrm{w}$ dolnej części otworu nie ma znaczącego wpływu na energię wyrzutu elementu skały będącego w górnej części ściany eksploatacyjnej proponuje się przyjąć, że na elementarną cząstkę skały oddziaływuje energia wywołana detonacją nie całego ładunku znajdującego się w otworze strzałowym, lecz jego górna część o długości równej zabiorowi,

- detonowany ładunek w dolnych partiach urabianej ściany w niewielkim stopniu oddziałuje na masy skały będące w górnych partiach,

- na element skały "A” rozmieszczonej w strefie urabiania (zabiór „lz”) działa energia wywołana detonacją ładunku MW ograniczona jego długością „lł”.

W warunkach strzelania ładunkami w otworach dużą trudnością jest określenie wskaźnika działania, dlatego proponuje się określać wskaźnik działania poprzez przyjęcie wskaźnika energetycznego strzelania jakim jest jednostkowe zużycie MW „q”. Tym samym można wyznaczać wartość wskaźnika działania ładunku w oparciu o zużycie jednostkowe (Barański, 2015):

$$
n=\frac{q_{r z}}{q_{o b}}
$$

gdzie:

$n$ - wskaźnik działania ładunku [-],

$q_{r z}$ - rzeczywisty wskaźnik zużycia MW oblicza się dzieląc ilość MW w „n-tej” części otwou strzałowego przez faktyczną objętość urabianej skały z analizowanej części otworu $\left[\mathrm{kg} / \mathrm{m}^{3}\right]$, $q_{o b}$ - projektowana ilość MW na urobienie $\mathrm{m}^{3}$ skały obliczona np. ze wzoru Suchanowa-Kutuzowa $\left[\mathrm{kg} / \mathrm{m}^{3}\right]$.

$q_{r z}=\frac{Q ł}{V ł}$

gdzie:

$V \nmid$ - objętość calizny skalnej urobionej z aktywnej części ładunku $\left[\mathrm{m}^{3}\right]$,

$O t$ - ilość ładunku MW w aktywnej części otworu [kg].

Zużycie jednostkowe określone jest wzorem Kutuzowa-Suchanowa:

$q=0,13 * \gamma * \sqrt[4]{f} *\left(0,6+3,3 * 10^{-3} * d * d_{s}\right) *\left(\frac{0,5}{d_{k}}\right)^{0,4} *\left(\frac{1000}{Q}\right)$

$q$ - jednostkowe zużycie materiału wybuchowego $\left[\mathrm{kg} / \mathrm{m}^{3}\right]$,

$g$ - gęstość skały $\left[\mathrm{Mg} / \mathrm{m}^{3}\right]$,

$f$ - wskaźnik zwięzłości skały [-],

$d$-średnica otworów strzałowych [mm],

$d_{s}$ - średnia odległość między szczelinami w masywie [m],

$d_{k}$ - żądany rozmiar średniego ziarna $[\mathrm{m}]$,

$Q$ - ciepło wybuchu stosowanego MW $[\mathrm{kcal} / \mathrm{kg}]$.

\subsection{Ocena wpływu parametrów strzelania na zasięg rozrzutu}

Obecnie stosowane uwarunkowania prawne nie uwzględniają wpływu parametrów geometrycznych otworu oraz parametrów strzelania na zasięg strefy rozrzutu. Według tabeli z załącznika 4 rozporządzenia rozrzut jest zależny jedynie od długości otworu oraz kąta jego nachylenia. Dawniej w praktyce górniczej popartej wiedzą autorytetów z zakresu techniki strzelniczej stosowało się pojęcie otworu zwykłego-krótkiego definiowanego: „otwór krótki to otwór, którego długość jest mniejsza od $6 \mathrm{~m}$ i średnica mniejsza niż $60 \mathrm{~mm}$ ". Obecnie strzelanie otworami krótkimi ma miejsce wtedy gdy długość otworu jest mniejsza niż 6 m (Samujłło,1968).

Konsekwencją tak przyjętych definicji jak w Rozporządzeniu - „otwór krótki, otwór długi” jest wyznaczenie minimalnej strefy rozrzutu odłamków wokół miejsca strzelania, która wynosi:

- dla otworów krótkich pionowych i odchylonych od pionu nie więcej niż $20^{\circ}-300 \mathrm{~m}$,

- dla otworów długich pionowych i odchylonych od pionu nie więcej niż $20^{\circ}-200 \mathrm{~m}$.

$\mathrm{Na}$ rys. 3. przedstawiono dwa przypadki prowadzenia prac strzałowych: 
- a) otwór długi: $l_{\text {otw }}=12,5 \mathrm{~m}$, średnica $\mathrm{d}=105 \mathrm{~mm}$, zabiór $\mathrm{z}=3,5 \mathrm{~m}$,

- b) otwór krótki: $1_{\text {otw }}=5,5 \mathrm{~m}$, średnica $\mathrm{d}=105 \mathrm{~mm}$, zabiór $\mathrm{z}=3,8 \mathrm{~m}$,

- $\quad$ warunki budowy geologicznej są takie same w obu przypadkach,

- $\quad$ zastosowano ten sam materiał wybuchowy w obu otworach.

Analizując powyższy przykład można jednoznacznie stwierdzić, że koncentracja energii (ilość MW w otworze) w ujęciu jednostkowym (w $1 \mathrm{mb}$ otworu) jest taka sama w obu otworach. Bardziej wymownym wskaźnikiem decydującym o efekcie strzelania jest wskaźnik „q” - jednostkowego zużycie MW. Dla krótkiego otworu (przypadek b) wartość „q" jest mniejsza niż w przypadku strzelania długim otworem (przypadek a) ze względu na większy zabiór. Ryzyko zagrożeniem rozrzutu jest mniejsze dla krótkiego otworu niż dla długiego jednakże zalecane w tab. 2. załączniku nr 4 Rozporządzenia minimalne strefy rozrzutu są większe dla otworu krótkiego (Dz. U. 2017 nr 321).

$\mathrm{Na}$ rys. 4 zaprezentowano kolejną analizę pokazującą wpływ sytuacji terenowej na wartość rozrzutu prognozowanego rozrzutu. Podczas prowadzenia prac strzałowych nastąpiło tzw. zarywanie wsteczne. Analizując taki przypadek zauważa się, że zużycie jednostkowe „q” w górnej części ładunku z powodu mniejszego zabioru jest znacznie większe od dolnej strefy (zwiększony zabiór), Konsekwencją takiego strzelania będzie powiększona strefa rozrzutu.

Poniżej na rys. 5. wykonano symulacje zakresu zmieniającej się strefy oddziaływania rozrzutem dla ładunku "Q $\mathrm{Q}_{z}$ w otworze strzałowym o zadanej średnicy, który oddziałuje na skałę o ograniczonej objętości. Obliczenia przewidywanego zasięgu strefy rozrzutu wykonane przy założeniach: wysokość ściany $15 \mathrm{~m}$, kąt nachylenia otworu $80^{\circ}$, długość przybitki równa zabiorowi $-3,5 \mathrm{~m}$, średnica otworu strzałowego - 105 mm. Do obliczeń przyjęto długość aktywnej części ładunku (mającej bezpośredni wpływ na rozrzut) wynoszącą 3,5 m. Następnie dokonano modelowania wpływu zabioru na wskaźnik działania zwiększając i zmniejszając jego wartość. $\mathrm{W}$ ten sposób porównując zabiory obliczeniowe z rzeczywistym otrzymano wartości wskaźnika działania w różnych częściach otworu strzałowego odmienne od zakładanych.

Analizując powyższy wykres można dostrzec następujące prawidłowości:

- najmniejszy rozrzut uzyskano dla wartości wskaźni$\mathrm{ka}$ „n” poniżej 1. Natomiast przy $\mathrm{n}>1$ rozrzut osiąga wartość maksymalną niezależnie od zastosowanego wzoru obliczeniowego,

- wskaźnik działania ładunku można łatwo regulować dobierając odpowiedni zabiór a tym samym rozstaw otworów strzałowych. Z punktu widzenia rozrzutu optymalne jest projektowanie robót strzałowych $\mathrm{w}$ taki sposób by uzyskać wartość $\mathrm{n}<1$,

- $\quad$ zmniejszenie zabioru przyczynia się do zwiększenia zasięgu rozrzutu. Mniejsza objętość urabianej calizny skalnej (wynikająca z mniejszego zabioru) powodu- je wzrost wartości zużycia jednostkowego (ta sama ilość MW urabia mniejszą objętość skały) a tym samym przesycenie energetyczne urabianego ośrodka. Nadwyżka energia przekraczającej możliwości ośrodka skalnego intensyfikuje rozrzut odłamków.

Z przeprowadzonych analiz prognozowania zasięgu rozrzutu odłamków w robotach strzałowych widać wyraźnie, że zasięg ten nie zależy od zastosowanej metody strzelania tylko od ilości energii przypadającej na urobienie określonej objętości skały (Morawa, Lewicki, 2008). Przyjęte kryteria zasięgu stref rozrzutu określone w stosownych obecnie przepisach nie odpowiadają warunkom rzeczywistym prowadzonych robót strzałowych.

Przy ocenie przewidywanego zasięgu rozrzutu powinno brać się pod uwagę ilość energii propagowaną w wyniku detonacji materiału wybuchowego, która jest zależna głównie od ilości materiału wybuchowego wypełniającego otwór strzałowy. Szacowany zasięg rozrzutu jest uzależniony od:

- parametrów strzelania: zabiór, wskaźnik działania i zużycie jednostkowe,

- parametrów geometrycznych otworu: średnica, długość, kąt nachylenia,

- parametrów energetycznych MW: prędkość detonacji i ciepło właściwe zależnych od właściwości fizyko-chemicznych m.in. gęstość, składu chemicznego MW.

\section{Propozycja zmian w zakresie przepisów dotyczących wy- znaczania zasięgu rozrzutu}

Ponieważ jak ustalono zasięg rozrzutu jest zależny od ilości MW wypełniającej otwór strzałowy, a na aktywną górną część ładunku większy wpływ ma średnica otworu niż jego długość autorzy proponują wprowadzenie zmian w załączniku 4 rozporządzenia:

- zaleca się przyjęcie dodatkowego podziału otworów strzałowych niezależnie od ich długości:

„Ze względu na średnice otwory strzałowe dzieli się na: - małośrednicowe o średnicach do $60 \mathrm{~mm}$,

- normalnośrednicowe o średnicach $\mathrm{w}$ przedziale 60-110 mm,

- wielkośrednicowe o średnicach powyżej $110 \mathrm{~mm}$."

- $\quad \mathrm{w}$ przypadku prowadzenia prac normalnośrednicowymi otworami strzałowymi wartość zasięgu rozrzutu przyjmowano by według tabeli $\mathrm{nr} 1 \mathrm{z}$ załącznika 4 rozporządzenia. Dla otworów małośrednicowych ze względu na mniejsze zagrożenie przyjmować wartości zmniejszone, a w przypadku otworów wielkośrednicowych stosować wartość zwiększoną w stosunku do określonej w tabeli załącznika 4.

- proponowane jest także zmiana sposobu określania wskaźnika działania „n” stosując wzór (8). Natomiast rzeczywiste zużycie jednostkowe wyznaczać z zależności (9).

- W przypadku prowadzenia prac strzałowych w skałach węglanowych, silnie spękanych lub cechujących się silnymi zaburzeniami tektoniki i obniżoną zwięzłością zaleca się obowiązkowo stosować obniżony wskaźnik działania „n”. 


\section{Literatura - References}

1. Barański K.: Empiryczne metody szacowania zasięgu strefy rozrzutu w górnictwie odkrywkowym. Międzynarodowa Konferencja „Blasting Techniques 2016” Stará Lesná 19.05.2016-20.05.2016 - materiały konferencyjne

2. Barański K.: Prowadzenie robót strzałowych w warunkach ograniczenia rozrzutu odłamków. Międzynarodowa Konferencja „Blasting Techniques 2015” Stará Lesná 21.05.2015-22.05.2015 - materiały konferencyjne

3. Barański K., Morawa R: Technologiczne możliwości zmniejszania zasięgu strefy rozrzutu w górnictwie odkrywkowym. Górnictwo Odkrywkowe 2015 R. 56 nr 3.

4. Morawa R.; Lewicki J.: Możliwości sterowania koncentracją energii MW w otworze strzałowym. Materiały Konferencji „BlastingTechniques”. Słowacja 2008.

5. Korzeniowski J., Onderka Z.: Roboty strzelnicze w górnictwie odkrywkowym. Wydawnictwa i Szkolenia Górnicze, Wrocław 2006.

6. Sulima Samujłło J.: Roboty strzelnicze w górnictwie odkrywkowym. Wyd. „Śląsk”, Katowice 1968 r.

7. Dz. U. 2017 nr 321 Rozporządzeniu Ministra Energii z dnia 9 listopada 2016 r. w sprawie szczegółowych wymagań dotyczących przechowywania i używania środków strzałowych i sprzętu strzałowego w ruchu zakładu górniczego.

\section{Remarks on the Interpretation of Rules for Determining the Range of Scattering of Rock Fragments in Blasting Works}

The paper discusses the types of methods of performing blasting works in relation to scattering of rock fragments. The principles of defining hazard scattering zones around blasting works are described in the current legislation. Suggestions were made regarding the valuation of scattering depending on the shooting parameters (eg. unit consumption), taking into account the legal regulations for estimating the range of scattering using various shooting methods.

Keywords: shooting methods, operation indicator, unit consumption, scattering zone 
